\author{
(Cardiac allograft vasculopathy nowadays)
}

\author{
Tomáš Eckhardt, Michal Pazderník
}

Klinika kardiologie, Institut klinické a experimentální medicíny, Praha

INFORMACE O ČLÁNKU

Historie článku:

Vložen do systému: 10. 11. 2020

Prijat: 17. 11. 2020

Dostupný online: 13. 1. 2021

\section{Klíčová slova:}

Intimální hyperplazie

Koronární nemoc srdečního štěpu

Optická koherenční tomografie

Transplantace

Keywords:

Cardiac allograft vasculopathy Intimal hyperplasia

Optical coherence tomography

Transplantation
SOUHRN

Koronární nemoc srdečního štěpu (KNSŠ) je hlavní příčinou pozdní morbidity a mortality pacientů po transplantaci srdce a výrazně zkracuje jejich dlouhodobé přežití. Je pro ni typická difuzní koncentrická intimální hyperplazie, která se manifestuje ve formě časného stenotického postižení koronárních tepen. Diagnóza by měla být stanovena na základě kombinace nálezů a výsledků z neinvazivních a invazivních vyšetření. Léčebné možnosti jsou omezené, proto je prevence jejího rozvoje zcela esenciální. Tento článek pojednává o epidemiologii, př́znacích, patogenezi, rizikových faktorech, diagnostice a léčbě tohoto onemocnění.

(c) 2021, ČKS.

\section{ABSTRACT}

Cardiac allograft vasculopathy is the main cause of late morbidity and mortality in heart transplant patients and significantly shortens their long-term survival. It is characterized by a diffuse concentric intimal hyperplasia, which manifests itself in the form of early stenotic coronary artery disease. The diagnosis should be made on the basis of a combination of findings from non-invasive and invasive examinations. Treatment options are limited, hence prevention of its development is crucial. This article discusses the epidemiology, symptoms, pathogenesis, risk factors, diagnosis and treatment of this disease.

\section{Úvod}

Vaskulopatie štěpu byla po řadu let opomíjenou klinickou jednotkou a často je př́liš pozdě diagnostikována jako nově vzniklá srdeční dysfunkce neznámé etiologie. ${ }^{1}$ Na rozdíl od aterosklerotické ischemické choroby srdeční (ICHS) postihující nativní koronární tepny se vznikem fokálních, excentrických stenóz epikardiálních koronárních tepen je koronární nemoc srdečního štěpu (KNSŠ) v časných stadiích charakterizována difuzním ztluštěním intimy epikardiálních i intramyokardiálních tepen srdečního štěpu s následným zúžením průsvitu a uzávěrem malých tepen. ${ }^{2}$ I přes pokrok v imunosupresivní terapii je toto onemocnění jednou z hlavních prríčin pozdní mortality 5-10 let po srdeční transplantaci (32,3\%), převyšující př́ispěvky malignit $(24,9 \%)$ a infekcí $(10,8 \%){ }^{3}$ Na rozvoji tohoto onemocnění se podílí spektrum imunitních a neimunitních faktorů. ${ }^{4}$ Diagnóza by měla být stanovena na základě kombinace nálezů a výsledků z neinvazivních a invaziv- ních vyšetření. Prevence a léčba KNSŠ je stále pouze omezená, a v některých případech selhání štěpu je nezbytná srdeční retransplantace. ${ }^{5}$ Tento článek pojednává o epidemiologii, př́iznacích, patogenezi, rizikových faktorech, diagnostice a léčbě tohoto onemocnění.

\section{Epidemiologie}

Po infekcích a rejekcích štěpu, které jsou typické pro časné období po ortotopické transplantaci srdce (OTS), jsou koronární nemoc srdečního štěpu spolu s maligními onemocněními vedoucími príčinami úmrtí v pozdním období (tj. více než jeden rok od transplantace). ${ }^{5} \mathrm{~V}$ prvním roku po transplantaci postihuje $8 \%$ pacientů, po pěti letech se vyskytuje ve $30 \%$ a až u poloviny př́ijemců je možné KNSŠ detekovat v období deseti let po transplantaci. ${ }^{6}$ Detekce známek KNSŠ v podobě progredujícího ztluštění intimální vrstvy koronárních tepen $v$ prvním roce po transplantaci 
představuje známku vysokého rizika pro budoucí kardiovaskulární příhody. ${ }^{7}$

\section{Klinické projevy}

Během OTS dochází k přetětí postgangliových nervových axonů, proto je dárcovské srdce denervováno, a z toho pramení závažnost povahy KNSŠ. Typický projev koronární ischemie, angina pectoris, není proto u pacientů s KNSŠ přítomná. Existují však údaje o částečné reinervaci srdečního štěpu po letech od transplantace. ${ }^{8}$ Mezi projevy KNSŠ patří symptomy, které nemusejí být prvotně velmi specifické, patří mezi ně snížená tolerance námahy či dušnost. Z těch vážnějších se mohou vyskytnout arytmie, srdeční selhání, synkopa nebo akutní koronární syndrom či náhlá srdeční smrt. S ohledem na tuto skutečnost, je nutné se na pátrání a sledování eventuálních projevů KNSŠ v rámci pravidelných kontrol zaměřit. Stanovení diagnózy KNSŠ může být proto výzvou, a pravidelné kontroly pacientů po transplantaci srdce by měly být také doprovázeny elektrokardiografickým a echokardiografickým vyšetřením.

\section{Patogeneze}

KNSŠ je akcelerovaný fibroproliferativní proces, na jehož vzniku se podílejí imunologické a neimunologické faktory. ${ }^{4}$ Klíčovým bodem, na který tyto příčinné faktory působí, je cévní endotel, respektive jeho poškození. Endoteliální výstelka zajištuje cévní homeostázu prostřednictvím vaskulárního tonu, protidestičkové aktivity a inhibice proliferace svalových buněk. U KNSŠ poškození endotelu zahajuje a spouští kaskádu nadměrných mechanismů opravy tkání zahrnující vaskulární proliferace buněk, fibrózy a remodelace. ${ }^{9}$ Hlavním podkladem rozvoje KNSŠ je proliferace a migrace hladkých svalových buněk z tunica media, akumulace a ukládání zánětlivých buněk a lipidů způsobující difuzní intimální zesílení. ${ }^{10}$

Intravaskulární zobrazovací metody prokázaly, že onemocnění rychle progreduje již během prvního roku po transplantaci ${ }^{11}$ a má dvoufázovou reakci zahrnující počáteční intimální zesílení s expanzí membrana elastica externa, a tedy ještě s relativním ušetřením lumen tepny. Následně pak dochází ke konstriktivní remodelaci a zúžení lumen. Složení plátu se postupem času mění z fibrotického na ateromatózní, aterotrombotický až kalcifikovaný. ${ }^{12}$

\section{Imunologické faktory}

Po transplantaci srdce dochází ke komplexní imunologické reakci. Endoteliální buňky dárcovského srdce vytvářejí pro př́ijemce cizí HLA (human leukocyte antigens, lidské leukocytární antigeny), které jsou rozpoznány příjemcovými T-lymfocyty. Aktivované T-lymfocyty produkují cytokiny (interleukiny 2, 4, 5, 6, interferon gama, tumor nekrotizující faktor alfa), čehož následkem dochází k jejich proliferaci a změně regulace endoteliálních adhezivních molekul (intracelulární adhezivní molekuly [ICAM-1], vaskulární intercelulární adhezivní molekula-1 [VCAM-1] a P-selektin). Výsledkem tohoto procesu je aktivace endotelu a migrace zánětlivých buněk. Poté, co makrofágy proniknou do intimální vrstvy, začnou produkovat cytokiny (interleukin-1 a interleukin-6, tumor nekrotizující faktor alfa) a růstové faktory (destičkové růstové faktory [PDGF], transformující růstový faktor [TGF] alfa a beta). Tyto látky způsobí přesun buněk hladkých svalů do intimy, proliferaci a vznik depozit extracelulární matrix. ${ }^{13} \mathrm{~V}$ rámci in vitro studií byla popsána úloha humorální imunity s vysokými titry HLA protilátek třídy 1 stimulujících proliferaci buněk endotelu a hladkých svalů cestou aktivace mTOR/ S6 kinázy (mammalian target of rapamycin). ${ }^{14}$ Stejně tak dochází k redistribuci intracelulárního růstového faktoru fibroblastů do plazmatické membrány. Př́tomnost HLA protilátek v cirkulaci je spojována s vyšší mírou rejekce a rozvoje KNSŠ. ${ }^{9}$ Recentně byl také dokonce popsán efekt donor specifických HLA protilátek na progresi mediální vrstvy koronárních tepen. ${ }^{15}$

\section{Neimunologické faktory}

Společnou podstatou neimunologických faktorů, která zvyšuje riziko vzniku KNSŠ, je dysfunkce endotelu, aktivace koagulace a podpora nespecifického zánětu. Mezi tyto faktory patři klasické kardiovaskulární rizikové faktory - věk, pohlaví, index tělesné hmotnosti (BMI) prríjemce, diabetes mellitus, arteriální hypertenze, kouření, dyslipidemie. ${ }^{5} \mathrm{Z}$ dalších příčin můžeme jmenovat napríklad ischemicko-reperfuzní poškození či příčinu mozkové smrti dárce. ${ }^{16}$ Infekce cytomegalovirem (CMV) je další možnou příčinou rozvoje KNSŠ. Předpokládá se, že následkem infekce CMV dochází ke spuštění imunitní odpovědi vưči srdečnímu štěpu. Důsledkem je proliferace buněk zánětu a zvýšení hodnoty cytokinů a chemokinů, ${ }^{17}$ což podporuje aterogenní proces. CMV taky ovlivňuje vazodilataci zprostředkovanou endoteliální syntázou oxidu dusnatého (NOS) tím, že zvyšuje produkci inhibitoru této syntázy, kterým je asymetrický dimetylarginin (ADMA). Existují taky důkazy o schopnosti CMV způsobit imunitně zprostředkované poškození endotelu. ${ }^{9}$

Negativní vliv sinusové tachykardie na rozvoj KNSŠ se u denervovaných štěpů, kdy převládá efekt sympatiku, spíše neprokázal. ${ }^{18}$

\section{Diagnostika}

Pravidelné sledování a lékařské kontroly jsou pro včasnou diagnostiku KNSŠ nezbytné, jelikož jsou pacienti po denervaci štěpu většinou bez príznaků. Diagnostika klinicky němé KNSŠ je vždy velkou výzvou. $V$ rámci neinvazivních zobrazovacích metod neexistuje žádné vyšetření, které by mělo dostatečnou senzitivitu či specificitu na potvrzení př́tomnosti KNSŠ. Na druhou stranu invazivní vyšetřovací metody s sebou vždy nesou rizika samotného intervenčního výkonu.

\section{Neinvazivní zobrazovací metody}

Elektrokardiogram (EKG) - základní vyšetření, jakým je EKG, má velmi limitovanou výpovědní hodnotu s ohledem 
na četné abnormality, které se u pacientů po transplantaci na záznamu mohou vyskytovat, např. patologické vlny $\mathrm{Q}$, elevace nebo deprese úseku ST a inverze vln T. ${ }^{19}$

Klidové echokardiografické vyšetření může detekovat sníženou funkci levé komory srdeční nebo poruchy kinetiky jako následek ischemie myokardu.

Zátěžová echokardiografie s využitím dobutaminu může výše uvedené patologické nálezy zvýraznit a má z neinvazivních metod nejvyšší výpovědní hodnotu. Senzitivita, specificita, pozitivní a negativní prediktivní hodnota proti intravaskulárnímu ultrazvuku (IVUS) byla $72 \%, 83 \%, 88 \%$ a $62 \% .{ }^{20}$ Hodnocení myokardiálního strainu či použití kontrastní echokardiografie při hodnocení koronární průtokové rezervy jsou modalitami, které jsou v poslední době častěji používány ke zvýšení diagnostické přsnosti. ${ }^{5}$

CT angiografie (CTA) je atraktivní nově nastupující zobrazovací metoda vhodná ke sledování rozvoje KNSŠ, jež má potenciál v budoucnu nahradit klasickou invazivní koronární angiografii. Možnými překážkami jejího širokého přijetí je negativní vliv vysoké klidové srdeční frekvence na kvalitu obrazu, prostorové rozlišení, které omezuje hodnocení tepen v průměru menších než $2 \mathrm{~mm}$, potřeba použití jodové kontrastní látky a radiační expozice. Metaanalýza 13 studií zahrnujících 615 pacientů ukázala, že oproti konvenční angiografii dokázala CTA detekovat významnou KNSŠ se senzitivitou $94 \%$, specificitou $92 \%$, negativní prediktivní hodnotou $99 \%$, pozitivní prediktivní hodnotou $67 \%$ a diagnostickou přesností $94 \%{ }^{21} \mathrm{~S}$ nadšením bylo nedávno představeno neinvazivní hodnocení frakční průtokové rezervy jako součástí CTA, tato technologie $v$ sobě nese potenciál poskytnout $v$ budoucnu současně neinvazivní funkční a anatomické hodnocení. ${ }^{22}$

Dalšími neinvazivními zobrazovacími metodami, které se však v České republice u pacientů po transplantacích neprovádějí, jsou pozitronová emisní tomografie, tomografická scintigrafie či magnetická rezonance. ${ }^{21}$

\section{Invazivní zobrazovací metody}

Selektivní koronarografie (SKG) je zlatým standardem v detekci KNSŠ. ${ }^{9}$ Přes její prognostickou užitečnost, je však toto vyšetření limitováno neschopností vizualizace mimo arteriální lumen. V prípadě difuzního koncentrického postižení a rozsáhlé remodelace cév u pacientů s KNSŠ je tedy její diagnostická přesnost omezená. Další limitací je potřeba použití jodové kontrastní látky, která může způsobit zhoršení již tak fragilních ledvinných funkcí. Časový harmonogram provádění SKG se u transplantačních center liší, v ČR se typicky provádí v 1. a 12. měsíci po transplantaci. ${ }^{23} \mathrm{~V}$ případě, že je vysloveno podezření na KNSŠ, je provedení SKG indikováno ad hoc. Angiografie může odhalit intraluminální stenózy či zpomalení toku v koronárním řečišti, a to zejména v jeho distálním povodí (obr. 1). K odlišení koronárního vazospasmu od postižení KNSŠ se využívá aplikace vazodilatačně působících látek. Tabulka 1 nám představuje klasifikační nomenklaturu KNSŠ vydanou Mezinárodní společností pro transplantace srdce a plic (ISHLT) v roce $2010 .^{9}$

Intravaskulární ultrazvuk (IVUS) je důležitou zobrazovací metodou $v$ detekci angiograficky němé KNSŠ. Jeho předností je možnost detekovat patologické koncentrické ztluštění koronární tepny, dokáže zhodnotit rozmě-

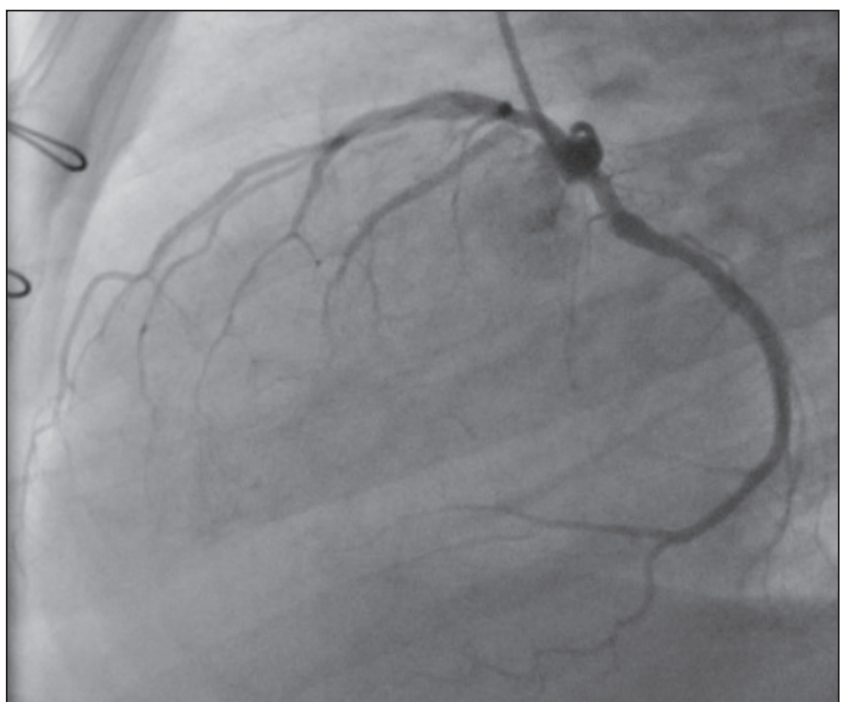

Obr. 1 - Koronární nemoc srdečního štěpu u pacienta čtyři roky po transplantaci srdce. Selektivní koronarografie levé koronární tepny: nerovnosti kmene, na ramus interventricularis anterior proximálně stenóza kolem $50-60 \%$, stenózy do $50 \%$ na ramus circumflexus a ramus marginalis sinister, periferie všech větví je vychudlá a amputovaná.

Tabulka 1 - Klasifikační systém pro koronární nemoc srdečního štěpu dle ISHLT

\begin{tabular}{|c|c|}
\hline Stupeň závažnosti & Angiografická kritéria \\
\hline CAV 0 - nevýznamný & Žádná detekovatelná stenóza \\
\hline CAV 1 - mírný & $\begin{array}{l}\text { Stenóza ACS }<50 \% \text { nebo } \\
\text { stenóza primární větve }<70 \% \text { nebo } \\
\text { stenóza vedlejší větve }<70 \%\end{array}$ \\
\hline CAV 2 - střední & $\begin{array}{l}\text { Stenóza ACS }<50 \% \text { nebo } \\
\text { stenóza jedné z primárních větví } \\
\geq 70 \% \text { nebo } \\
\text { izolovaná stenóza vedlejší větve ve dvou } \\
\text { povodích } \geq 70 \%\end{array}$ \\
\hline CAV 3 - závažný & $\begin{array}{l}\text { Stenóza ACS } \geq 50 \% \text { nebo } \\
\geq 2 \text { primární větve se stenózou } \geq 70 \% \\
\text { nebo } \\
\text { izolovaná stenóza vedlejší větve ve třech } \\
\text { povodích nebo } \\
\text { CAV } 1 \text { nebo CAV } 2 \text { se známkami dys- } \\
\text { funkce srdečního štěpu (EF LK } \leq 45 \% \text { ) } \\
\text { nebo známkami významné restrikce }\end{array}$ \\
\hline
\end{tabular}

Primární větev - označení pro proximální a střední třetinu RIA, RC, RIM a dominantní $A C D$. Vedlejší větev - označení pro úseky distální třetiny primárních větví nebo jakýkoliv segment s velkým septálním perforátorem, diagonální větve a ramus marginalis nebo nedominantní ACD. Restriktivní fyziologie srdečního štěpu - symptomatické srdeční selhání s echokardiografickým poměrem rychlosti E/A > 2, časem izovolumetrické relaxace kratším než 60 ms, restriktivními hemodynamickými nálezy včetně tlaku v pravé síní > $12 \mathrm{~mm} \mathrm{Hg}$, plicním kapilárním tlakem v zaklínění > $25 \mathrm{~mm}$ $\mathrm{Hg}$, srdečním výdejem $<2 \mathrm{l} / \mathrm{min} / \mathrm{m}^{2}$.

ACD - arteria coronaria dextra; ACS - arteria coronaria sinitra, levá věnčitá tepna; CAV - cardiac allograft vasculopathy, koronární nemoc srdečního štěpu; EF LK - ejekční frakce levé komory; ISHLT - International Society for Heart and Lung Transplantation; $\mathrm{RC}$ - ramus circumflexus; RIA - ramus interventricularis anterior; RIM - ramus intermedius. 


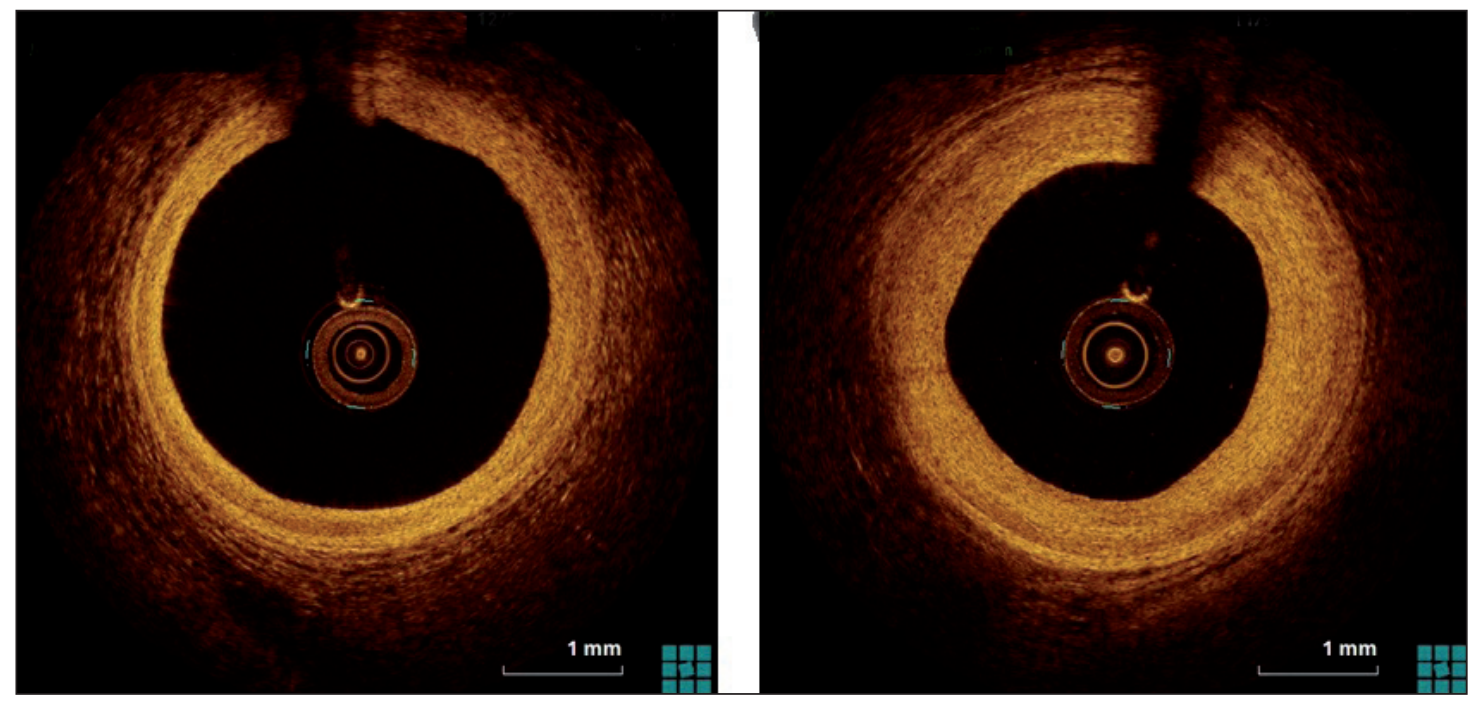

Obr. 2 - OCT vyšetření s průkazem extrémně rychlé progrese intimální hyperplazie u pacienta již jeden rok po transplantaci srdce (vlevo OCT v prvním měsíci po OTS, vpravo kontrolní vyšetření OCT ve 12. měsíci po OTS)

ry lumen tepny, vzhled a tloušt'ku intimy a medie (IMT). Za patologické se považuje již ztluštění IMT nad 0,3 $\mathrm{mm}$. Signifikantní je ztluštění IMT nad 0,5 mm, které, pokud je detekováno v prvním roce po OTS, může být spojeno s významně vyšší pravděpodobností vzniku úmrtí ze všech příčin, infarktu myokardu a z následného vzniku angiograficky významné KNSŠ.7 Hodnocení maximální tloušt'ky IMT také dokáže dobře predikovat pravděpodobnost rychle progredující KNSŠ. ${ }^{24}$ Nevýhodou IVUS je menší dostupnost, vyšší časová náročnost vyšetření, periprocedurální riziko a vyšší cena. V detekci KNSŠ má IVUS nezastupitelnou úlohu, a to hlavně v prípadech nevysvětlitelného selhání štěpu při absenci známek rejekce a normálním koronarografickém nálezu.

Optická koherenční tomografie (OCT) je v současnosti nejsenzitivnější metodou hodnocení KNSŠ. Oproti IVUS disponuje desetinásobně vyšším rozlišením (10-20 $\mu \mathrm{m})$ a poskytuje v jistém slova smyslu až obraz připomínající virtuální histologii. Nevýhodou je nutnost intrakoronárního podávání kontrastní látky. OCT od sebe dokáže precizně odlišit intimální a mediální vrstvu koronárních tepen a následně je i kvantifikovat, což může pomoci při diagnostice časné progrese tohoto onemocnění (obr. 2). ${ }^{11}$
Kromě tohoto kvantitativního hodnocení KNSŠ však také dokáže tepny zhodnotit i kvalitativně, a to s velkou precizností. Můžeme sledovat lipidové pooly související s klasickými aterosklerotickými pláty, kalcifikace, vrstvené fibrotické pláty („layered fibrotic plaque“) pravděpodobně odpovídající následku opakované intramurální trombózy a tzv. světlé skvrny („bright spots”) naznačující chronickou rejekci následkem infiltrace makrofágy. ${ }^{25}$ Bylo zjištěno, že nejsilnějšími prediktory progrese nefatální KNSŠ byla míra vrstvených fibrotických plátů a světlých skvrn. ${ }^{25}$

V tabulce 2 přinášíme základní charakteristiku dvou nejpřesnějších diagnostických metod KNSŠ.

Endomyokardiální biopsie (EMB) v současnosti slouží jako doplňující vyšetření při detekci KNSŠ. V případě, že je při EMB zjištěna patologie $v$ mikrovaskulárním povodí, může mít prognostický význam. Dle jedné monocentrické studie, při které byly histologickým rozborem analyzovány vzorky z EMB v rámci rutinních kontrol v prvním roce OTS, bylo zjištěno, že přítomnost stenotického postižení mikrovaskulárního řečiště byla spojena se snížením celkového přežití (10,9 versus 13,4 roku) a zvýšeného rizika fatálních kardiálních příhod (96\% versus 99 $\%$ v prvním roce a $76 \%$ versus $90 \%$ po deseti letech). ${ }^{26}$

\section{Tabulka 2 - Porovnání IVUS a OCT vyšetření}

\begin{tabular}{|l|l|l}
\hline Parametr & IVUS & OCT \\
\hline Rozlišovací schopnost & $<40 \mu \mathrm{m}$ u nejmodernějších zařízení & $<10 \mu \mathrm{m}$ \\
\hline Penetrace & $4-8 \mathrm{~mm}$ & $2-3 \mathrm{~mm}$ \\
\hline Kvantifikace objemu plátu & Možná díky vysoké penetraci & Obtížná u širokých plátů \\
\hline Zobrazení př́tomnosti remodelace & Možná díky vysoké penetraci & Obtížná u širokých plátů \\
\hline $\begin{array}{l}\text { Zobrazení vlastností vulnerabilního } \\
\text { plátu }\end{array}$ & Obtížná pro nedostatečné rozlišení & Možná díky vysokému rozlišení \\
\hline Použití kontrastní látky & Nevyžaduje & Potřeba eliminace přítomnosti krve z lumen tepny \\
\hline Detekce trombu & Obtížná & Jednodušší \\
\hline Cena & Přibližně 30 tisíc Kč za jeden IVUS katétr & Přibližně 30 tisíc Kč za jeden OCT katétr \\
\hline
\end{tabular}

IVUS - intravaskulární ultrazvuk; OCT - optická koherenční tomografie. 
V neposlední řadě se mohou $k$ diagnostice KNSŠ použít metody analyzující koronární mikrocirkulaci - koronární průtoková rezerva (CFR) a frakční průtoková rezerva (FFR). ${ }^{5}$

\section{Prevence a léčba}

Management KNSŠ je zaměřen na primární prevenci, užití pravidelných zobrazovacích metod a včasnou léčbu. Zcela esenciální je ovlivnění klasických rizikových faktorů ischemické choroby srdeční, jako je nadváha, arteriální hypertenze, diabetes mellitus, dyslipidemie a kouření.

\section{Kyselina acetylsalicylová}

Empirické podávání prípravků s obsahem kyseliny acetylsalicylové (ASA) se opírá o předpoklad, že v oblastech poškození endoteliální vrstvy dochází $k$ tvorbě trombů. ${ }^{27}$ Několik studií in vitro prokázalo zvýšenou reaktivitu krevních destiček izolovaných od pacientů po transplantaci srdce, která byla typická zvýšenou tvorbou imunitních povrchových markerů aktivace stejně jako zvýšenou aktivitou po stimulaci. Ve studii se 120 pacienty po transplantaci srdce Kim a spol. prokázali, že i přes vysokou zátěž rizikových faktorů pro KNSŠ u pacientů užívající přípravek s obsahem kyseliny acetylsalicylové (ASA) byl silný inverzní vztah k rozvoji střední až těžké KNSŠ při pětiletém angiografickém sledování. ${ }^{28}$ Jiná studie posuzovala po dobu 15 let efekt časného nasazení ASA, podávané od prvního měsíce po transplantaci srdce. U 97 pacientů užívajících ASA, kteří byli srovnáváni se skupinou 109 pacientů, kteři ASA neužívali, byla míra výskytu KNSŠ u pacientů užívajících kyselinu acetylsalicylovou šestinásobně nižší (7 \% versus $37 \%) .29$

\section{Statiny (hypolipidemika)}

Statiny jsou standardní léčbou pacientů po OTS, zlepšují přežití a snižují incidenci a závažnost KNSŠ. ${ }^{30} \mathrm{~V}$ literatuře existují pozitivní zkušenosti s využitím pravastatinu a simvastatinu. ${ }^{31} \mathrm{Na}$ našem pracovišti jsou pacienti léčeni atorvastatinem, u kterého se snažíme o maximalizaci dávek dle pravidelných laboratorních a klinických kontrol.

\section{Imunosupresiva}

Inhibitory mTOR tlumí proliferaci T-lymfocytů a B-lymfocytů, mezi které patři everolimus a sirolimus. Svým účinkem také inhibují proliferaci cévní hladké svaloviny a proliferaci fibroblastů. Oba prípravky prokázaly konzistentní př́znivé účinky v prevenci rozvoje KNSŠ. ${ }^{32}$

Ve studii porovnávající efekt kombinace cyklosporinu A s mykofenolátem s kombinací cyklosporinu A a azathioprinu došlo ve skupině využívající mykofenolát $\mathrm{k}$ redukci tř́leté mortality nebo ztráty štěpu o $35 \% .^{33}$

\section{Vazodilatancia}

V literatuře se uvádí využití diltiazemu, který v jedné studii snížil pětiletou pravděpodobnost rozvoje KNSŠ o $26 \%$. $^{34}$

Použití inhibitorů ACE pomáhá snížit úroveň mikrovaskulární endoteliální dysfunkce, oxidačního stresu a aktivace endotelinu, a tím pádem má pozitivní vliv na zpomalení progrese tvorby plátů v dárcovském srdci. ${ }^{35}$

\section{Ganciklovir}

Absence adekvátní profylaxe CMV je spojena s větší progresí zúžení lumen koronárního řečiště. ${ }^{36}$ Právě zvládnutí subklinické replikace CMV po transplantaci může ovlivnit rejekci srdečního štěpu. Podávání gancikloviru tak pomáhá redukovat progresi KNSS̆. ${ }^{37}$

\section{Revaskularizace}

Revaskularizace pro KNSŠ je většinou limitována difuzním koronárním postižením. Perkutánní koronární intervence $(\mathrm{PCl})$ je většinou provedena pouze s cílem ošetřit významné fokální postižení. Zkušenosti s implantaci stentů do věnčitých tepen pacientů po transplantaci nejsou dostatečné. Četnost restenóz po PCI u pacientů s KNSS̆ je vysoká. ${ }^{38,39} \mathrm{Z}$ dostupných dat je známo, že katetrizační intervence jsou zatížení nižším rizikem mortality v porovnání s chirurgickou revaskularizací myokardu. Chirurgická revaskularizace myokardu je spojena s vysokým periprocedurálním rizikem až do $40 \% .{ }^{5}$ Výsledky revaskularizace jsou střednědobé ${ }^{40,41}$ Rizikem pro pacienta ale nadále zůstává další progrese nemoci s nutností katetrizační intervence nebo potřebou opětovného chirurgického zákroku.

\section{Retransplantace}

Poslední a definitivní možností zůstává retransplatace srdce, která má však horší výsledky s kratším přežitím, než když se jedná o první transplantaci. ${ }^{42,43}$ Retransplantace je možností pouze pro přísně selektovanou skupinu pacientů s významnou KNSŠ.

\section{Závěr}

Koronární nemoc srdečního štěpu představuje významný patologický proces multifaktoriální etiologie, který je pro svůj často asymptomatický charakter a plíživou progresi významnou prríčinou morbidity a mortality pacientů po transplantaci srdce. Časná diagnostika a standardizované preventivně-léčebné metody nám v současné době dokážou tento proces většinou pouze zpomalit. Pouze další pečlivé studium, nejlépe ve formě prospektivních randomizovaných studií, nám může pomoci toto onemocnění lépe pochopit a i následně účinně léčit.

\section{Literatura}

1. Lund LH, Edwards LB, Kucheryavaya AY, et a. International Society of Heart and Lung Transplantation. The registry of the International Society for Heart and Lung Transplantation: thirty-first official adult heart transplant report - 2014; focus theme: retransplantation. J Heart Lung Transplant 2014;33:996-1008.

2. Lu WH, Palatnik K, Fishbein GA, et al. Diverse morphologic manifestations of cardiac allograft vasculopathy: a pathologic study of 64 allograft hearts. J Heart Lung Transplant 2011;30:1044-1050.

3. Lund LH, Khush KK, Cherikh WS, et al. International Society for Heart and Lung Transplantation. The Registry of the International Society for Heart and Lung Transplantation: Thirty-fourth Adult Heart Transplantation Report - 2017; Focus Theme: Allograft ischemic time. J Heart Lung Transplant 2017;36:1037-1046.

4. Caforio AL, Tona F, Fortina $A B$, et al. Immune and nonimmune predictors of cardiac allograft vasculopathy onset and severity: multivariate risk factor analysis and role of immunosuppression. Am J Transplant 2004;4:962-970. 
5. Skorić B, Čikeš M, Ljubas Maček J, et al. Cardiac allograft vasculopathy: diagnosis, therapy, and prognosis. Croat Med J 2014;55:562-576.

6. Khush KK, Cherikh WS, Chambers DC, et al. International Society for Heart and Lung Transplantation. The International Thoracic Organ Transplant Registry of the International Society for Heart and Lung Transplantation: Thirty-sixth adult heart transplantation report - 2019; focus theme: Donor and recipient size match. J Heart Lung Transplant 2019;38:10561066. Erratum in: J Heart Lung Transplant 2020;39:91.

7. Schmauss $D$, Weis $M$. Cardiac allograft vasculopathy: recent developments. Circulation 2008;117:2131-2141.

8. Weis M, von Scheidt W. Cardiac allograft vasculopathy: a review. Circulation 1997;96:2069-2077.

9. Chih S, Chong AY, Mielniczuk LM, et al. Allograft Vasculopathy: The Achilles' Heel of Heart Transplantation. J Am Coll Cardiol 2016;68:80-91.

10. Pober JS, Jane-wit $D$, Qin L, Tellides $G$. Interacting mechanisms in the pathogenesis of cardiac allograft vasculopathy. Arterioscler Thromb Vasc Biol 2014;34:1609-1614.

11. Pazdernik M, Chen Z, Bedanova $\mathrm{H}$, et al. Early detection of cardiac allograft vasculopathy using highly automated 3-dimensional optical coherence tomography analysis. J Heart Lung Transplant 2018;37:992-1000.

12. Tsutsui $H$, Ziada KM, Schoenhagen $P$, et al. Lumen loss in transplant coronary artery disease is a biphasic process involving early intimal thickening and late constrictive remodeling: results from a 5-year serial intravascular ultrasound study. Circulation 2001;104:653-657.

13. Kummer L, Zaradzki M, Vijayan V, et al. Vascular Signaling in Allogenic Solid Organ Transplantation - The Role of Endothelial Cells. Front Physiol 2020;11:443.

14. Zhang X, Reed EF. Effect of antibodies on endothelium. Am J Transplant 2009;9:2459-2465.

15. Pazdernik M, Bedanova $\mathrm{H}$, Chen Z, et al. Donor specific anti-HLA antibodies and cardiac allograft vasculopathy: A prospective study using highly automated 3-D optical coherence tomography analysis. Transpl Immunol 2020 Oct 15:101340. doi: 10.1016/j.trim.2020.101340. Epub ahead of print.

16. Johnson MR. Transplant coronary disease: nonimmunologic risk factors. J Heart Lung Transplant 1992;11(3 Pt 2):S124-S132.

17. Nikolova AP, Kobashigawa JA. Cardiac Allograft Vasculopathy: The Enduring Enemy of Cardiac Transplantation. Transplantation 2019;103:1338-1348.

18. Pazdernik $M$, Wichterle $D$, Chen $Z$, et al. Heart rate and early progression of cardiac allograft vasculopathy: A prospective study using highly automated 3-D optical coherence tomography analysis. Clin Transplant 2020;34:e13773.

19. Pickham D, Hickey K, Doering L, et al. Electrocardiographic abnormalities in the first year after heart transplantation. J Electrocardiol 2014;47:135-139.

20. Sade LE, Eroğlu S, Yüce $D$, et al. Follow-up of heart transplant recipients with serial echocardiographic coronary flow reserve and dobutamine stress echocardiography to detect cardiac allograft vasculopathy. J Am Soc Echocardiogr 2014;27: 531-539.

21. Wever-Pinzon O, Romero J, Kelesidis I, et al. Coronary computed tomography angiography for the detection of cardiac allograft vasculopathy: a meta-analysis of prospective trials. J Am Coll Cardiol 2014;63:1992-2004.

22. Budde $R$, Nous $F$, Roest $S$, et al. Non-Invasive Functional Coronary Artery Evaluation by CT-Derived Fractional Flow Reserve (FFRct) in Heart Transplant Patients. J Heart Lung Transplantation 2020;39(Suppl.):S62.

23. Maxian R, Kautzner J, Málek I, et al. Časná progrese vaskulopatie srdečního štěpu hodnocená kvantitativní koronární angiografií: monocentrická prospektivní studie. Cor Vasa 2018;60:e59-e65.

24. Chen Z, Pazdernik M, Zhang $\mathrm{H}$, et al. Quantitative 3D Analysis of Coronary Wall Morphology in Heart Transplant Patients: OCT-Assessed Cardiac Allograft Vasculopathy Progression. Med Image Anal 2018;50:95-105.
25. Clemmensen TS, Holm NR, Eiskjær $\mathrm{H}$, et al. Layered Fibrotic Plaques Are the Predominant Component in Cardiac Allograft Vasculopathy: Systematic Findings and Risk Stratification by OCT. JACC Cardiovasc Imaging 2017;10:773-784.

26. Hiemann NE, Wellnhofer E, Knosalla C, et al. Prognostic impact of microvasculopathy on survival after heart transplantation: evidence from 9713 endomyocardial biopsies. Circulation 2007;116:1274-1282.

27. Dzeshka MS, Shantsila A, Lip GY. Effects of Aspirin on Endothelial Function and Hypertension. Curr Hypertens Rep 2016;18:83.

28. Kim M, Bergmark BA, Zelniker TA, et al. Early aspirin use and the development of cardiac allograft vasculopathy. J Heart Lung Transplant 2017;36:1344-1349.

29. Peled $Y$, Lavee J, Raichlin E, et al. Early aspirin initiation following heart transplantation is associated with reduced risk of allograft vasculopathy during long-term follow-up. Clin Transplant 2017;31(12). doi: 10.1111/ctr.13133.

30. Paraskevas KI. Applications of statins in cardiothoracic surgery: more than just lipid-lowering. Eur J Cardiothorac Surg 2008;33:377-390.

31. Mehra MR, Uber PA, Vivekananthan K, et al. Comparative beneficial effects of simvastatin and pravastatin on cardiac allograft rejection and survival. J Am Coll Cardiol 2002;40:1609-1614.

32. Arora S, Andreassen AK, Karason $\mathrm{K}$, et al. SCHEDULE (Scandinavian Heart Transplant Everolimus De Novo Study With Early Calcineurin Inhibitors Avoidance) Investigators. Effect of Everolimus Initiation and Calcineurin Inhibitor Elimination on Cardiac Allograft Vasculopathy in De Novo Heart Transplant Recipients. Circ Heart Fail 2018;11:e004050.

33. Eisen HJ, Kobashigawa J, Keogh A, et al. Mycophenolate Mofetil Cardiac Study Investigators. Three-year results of a randomized, double-blind, controlled trial of mycophenolate mofetil versus azathioprine in cardiac transplant recipients. J Heart Lung Transplant 2005;24:517-525.

34. Schroeder JS, Gao SZ, Alderman EL, et al. A preliminary study of diltiazem in the prevention of coronary artery disease in heart-transplant recipients. N Engl J Med 1993;328:164-170.

35. Steinhauff S, Pehlivanli S, Bakovic-Alt R, et al. Beneficial effects of quinaprilat on coronary vasomotor function, endothelial oxidative stress, and endothelin activation after human heart transplantation. Transplantation 2004;77:1859-1865.

36. Fearon WF, Potena L, Hirohata A, et al. Changes in coronary arterial dimensions early after cardiac transplantation. Transplantation 2007;83:700-705.

37. Valantine HA. Cardiac allograft vasculopathy: central role of endothelial injury leading to transplant "atheroma". Transplantation 2003;76:891-899.

38. Jonas M, Fang JC, Wang JC, et al. In-stent restenosis and remote coronary lesion progression are coupled in cardiac transplant vasculopathy but not in native coronary artery disease. J Am Coll Cardiol 2006;48:453-461.

39. Simpson L, Lee EK, Hott BJ, et al. Long-term results of angioplasty vs stenting in cardiac transplant recipients with allograft vasculopathy. J Heart Lung Transplant 2005;24:12111217.

40. Patel VS, Radovancevic B, Springer W, et al. Revascularization procedures in patients with transplant coronary artery disease. Eur J Cardiothorac Surg 1997;11:895-901.

41. Musci M, Loebe M, Wellnhofer E, et al. Coronary angioplasty, bypass surgery, and retransplantation in cardiac transplant patients with graft coronary disease. Thorac Cardiovasc Surg 1998; $46: 268-274$

42. Srivastava R, Keck BM, Bennett LE, Hosenpud JD. The results of cardiac retransplantation: an analysis of the Joint International Society for Heart and Lung Transplantation/United Network for Organ Sharing Thoracic Registry. Transplantation 2000;70:606-612

43. Topkara VK, Dang NC, John R, et al. A decade experience of cardiac retransplantation in adult recipients. J Heart Lung Transplant 2005;24:1745-1750. 